\title{
Penentuan Alih Fungsi Lahan Marginal Menjadi Lahan Pangan Berbasis Algoritma K-Means di Wilayah Kabupaten Boyolali
}

\author{
${ }^{1)}$ Daniel Riano Kaparang ${ }^{2)}$ Eko Se diyono \\ ${ }^{1)}$ Fakultas Teknologi Informasi, UKSW, drkaparang@ hotmail.com \\ ${ }^{2)}$ Fakultas Teknologi Informasi, UKSW, ekosed1@yahoo.com
}

\begin{abstract}
Changes in land use for industrial development, public housing and so on continues to grow along with the increasing of the population. Meanwhile, development of food security, continue to have problems, one of them is wide area of foodland. This study, build an analysis model to supporting variable land suitability against development of marginal land for opening primary food land as an information system. By using $K$-Means algorithm and focus on the data flow to become information, this study recommends a model of optimization analysis of marginal land to assist Agricultural Department in improving the agricultural service area to plant crops.
\end{abstract}

Key words : Analysis model, K-Means, Marginal Land, Land Food, Characteristic Of The Land

\begin{abstract}
Abstrak
Perubahan fungsi lahan pangan untuk pembangunan industri, perumahan rakyat dan sebagainya, terus berkembang seiring dengan meningkatnya populasi penduduk. Sementara itu pembangunan ketahanan pangan terus mengalami kendala salah satunya luas area lahan pangan. Penelitian ini membangun model analisis variabel pendukung kesesuaian lahan terhadap pengembangan lahan mag inal untuk pe mbukaan lahan pangan sebagai suatu sistem informasi. Dengan menggunakan algoritma k-means dan fokus pada alur data untuk menjadi informasi, maka penelitian ini merekomendasikan model analisis optimasi terhadap lahan marginal untuk membantu dinas pertanian dalam meningkatkan luas area tanam tanaman pangan.
\end{abstract}

Kata Kunci: Model analisis, k-means, lahan marginal, lahan pangan, karakteristik lahan

\section{Pendahuluan}

Pentingnya perencanaan pengelolaan lahan menjadi salah satu faktor tercapainya optimasi tata guna lahan. Beberapa alasan pentingnya perencanaan pengelolaan lahan diantaranya keterbatasan jumlah lahan dan sumberdaya lahan yang non renewable, terjadinya kerusakan lahan akibat ketidak sesuaian fungsi lahan, area resapan air yang berkurang akibat alih fungsi lahan hutan menjadi lahan pertanian (Hardjowigeno dan Widiatmaka, 2007).

Tahun 2010 di kabupaten boyolali terdapat 16749.51 ha lahan marginal yang terus meluas tanpa pengendalian. Lahan tersebut meluas akibat bencana seperti erupsi gunung merapi, erosi, tanah longsor, perusakan hutan, pertanian sistem ladang berpindah dan sebagainya (BPS Kab. Boyolali, 2011).

Lahan marginal ini menjadi salah satu prioritas pemanfaatan kawasan budidaya terutama produksi pangan. Produk pangan yang menjadi komoditas unggulan berupa padi ladang, jagung, ubi jalar dan kacang tanah. Indikasi program pembangunan kabupaten Boyolali menyebutkan pemanfaatan lahan marginal menjadi salah satu program utama dalam pembangunan berkelanjutan kurun waktu 2011 hingga 2030. Hal ini diujukan untuk mengendalikan kebutuhan konsumsi pangan di daerah, nasional dan luar negeri (LKPJ Bupati Kab. Boyolali, 2009). Pemanfaatan lahan marginal untuk lahan pangan sebagai awal menjaga stabilitas ketahanan pangan dan peningkatan perekonomian petani, disamping itu secara alamiah menjaga kelestarian ekosistem serta mengurangi pembukaan lahan pertanian dari lahan hutan.

Dalam mengidentifikasi variabel-variabel evaluasi lahan maka dibutuhkan metode k-means untuk mengkonversi data evaluasi menjadi data numerik yang selanjutnya dianalisis dengan tujuan mendapatkan kelompok-kelompok data lahan marginal yang akan dijadikan bahan rujukan ke dinas pertanian agar dibuka menjadi lahan produk pangan tepat guna. 


\section{Kajian Pustaka}

Penelitian sebelumnya tentang evaluasi kesesuaian lahan untuk budidaya tanaman pangan menggunakan jaringan syaraf tiruan membahas jenis tanaman pangan berdasarkan karakteristik lahan sebagai variabel keputusan (Aziz, 2006). Penelitian ini menggunakan algoritma jaringan syaraf tiruan (JST) pendekatan learning vector quantization sebagai tools yang tepat dalam memberikan informasi cocok tanam. Hasilnya berupa nilai Eps (error minimum yang diharapkan) sebesar 0.005 yang menunjukan nilai yang cukup efektif dan efisien dalam melakukan prediksi jenis tanaman pangan untuk lahan tertentu.

Selanjutnya penelitian tentang sistem pakar penentuan kesesuaian lahan berdasarkan faktor penghambat terbesar (maximum limitation factor) untuk tanaman pangan, membahas 19 parameter dalam menentukan kesesuaian lahan. Objek yang digunakan adalah 14 jenis tanaman pangan dengan menggunakan metode fuzzy inference systems untuk memilih fungsi trapesium atau gauss dalam data processing (Sevani, 2009). Penelitian ini juga meperhitungkan faktor penghambat dan cara mengatasinya sesuai lokasi untuk suatu jenis tanaman pangan tertentu.

Penelitian saat ini dibandingkan dengan pemaparan penelitian di atas memiliki perbedaan dari segi metode, karakteristik data dan objek yang digunakan. Penelitian ini akan mendeskripsikan alur data yang dibentuk dalam model analisis dengan menggunakan k-means. Variabel di dalamnya bergantung pada karakteristik lahan terhadap lahan marginal.

\subsection{Evaluasi dan Klasifikasi Lahan}

Klasifikasi lahan merupakan pengembangan pemikiran dari sebuah sistem logika yang ekuivalen dengan kesesuaian lahan dalam karakeristiknya dan ditentukan melalui sifat-sifat lahan itu sendiri (Sitorus, 1985). Karakteristik ini dapat diamati secara langsung seperti keadaan geografis, tekstur dan kemiringan lereng. Ada juga yang harus diamati dengan melakukan penelitian laboratorium untuk mengetahui struktur mineral dan komposisi kimiawi tanah.

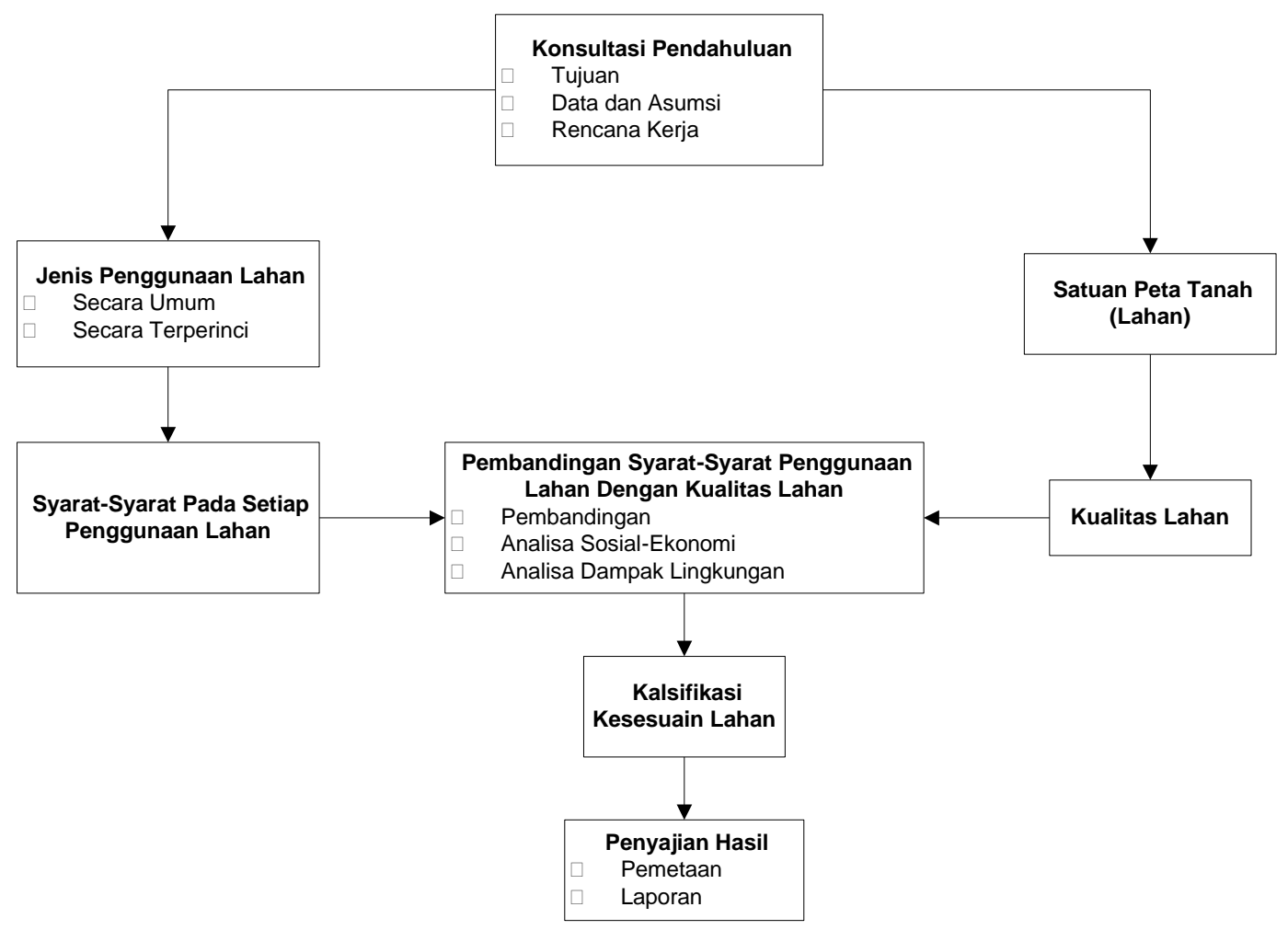

Gambar 1 A lur Kegiatan-Keg iatan dalam Evaluasi Lahan (FAO, 1981)

Lahan marginal dapat dinilai secara aktual dengan ketentuan lahan marginal yang akan dibuka memiliki riwayat pengelolaan lahan bidang pertanian, perkebunan atau peternakan. Karena 
jika termasuk lahan potensial, maka harus dilakukan usaha-usaha perbaikan terlebih dahulu (Hardjowigeno dan Widiatmaka, 2007).

Dalam membuat evaluasi kesesuaian lahan maka dibutuhkan gambaran kerangka evaluasi. Aktifitas-aktifitas utama dalam proses evaluasi kesesuaian lahan digambarkan dalam Gambar 2.1 adalah (FAO, 1981): Initial consultation meliputi perumusan tujuan evaluasi, data dan asumsi, rencana kerja evaluasi, Kind of land use, menjabarkan jenis lahan dan kegunaannya. Description land, maping, unit, melakukan pemetaan lahan beserta kualitas lahan berdasarkan pengetahuan untuk lahan tertentu dan batas-batasnya. Comparison of land use with land, membandingkan lahan dengan tipe-tipe lahan yang sudah ada berdasarkan data lahan, penggunaan lahan dan informasi ekonomi dan sosial disatukan untuk dianalisis bersama. Land suitability classification, hasil kesesuaian lahan untuk tujuan tertentu. Presentation of result, mempresentasikan hasil analisis kesesuaian lahan.

\subsection{Algoritma K-Means}

Himpunan data set $\mathrm{X}=\{\mathrm{x} 1, \mathrm{x} 2, \ldots, \mathrm{xn}\}$ dimana $\mathrm{x}_{\mathrm{i}}=\left(\mathrm{x}_{\mathrm{i} 1}, \mathrm{x}_{\mathrm{i} 2}, \ldots, \mathrm{x}_{\mathrm{ij}}\right)$ adalah vektor dalam ruang real $\mathrm{x}_{\mathrm{ij}} R$, di sini algoritma $\mathrm{k}$-means akan membagi $\mathrm{X}$ dalam $\mathrm{K}$ buah cluster dengan $\mathrm{K}>1$. Setiap cluster memiliki centroid (titik tengah) atau mean dari data dalam cluster tersebut (Alsabti., Sanjay Ranka., Vineet Singh, 2010).

$$
w_{j}=i_{l}, j \in\{1, \ldots, k\}, l \in\{1, \ldots, n\}
$$

Pertama, algoritma k-means memilih secara acak $\mathrm{k}$ buah data sebagai pusat cluster. Kemudian, jarak antara data dan pusat cluster dihitung menggunakan Euclidian distance. Data di tempatkan dalam cluster yang terdekat, dihitung dari titik tengah cluster. Pusat cluster baru akan ditentukan bila semua data telah di tempatkan dalam cluster terdekat. Proses penentuan pusat cluster dan penempatan data dalam cluster diulangi sampai nilai centroid tidak berubah lagi.

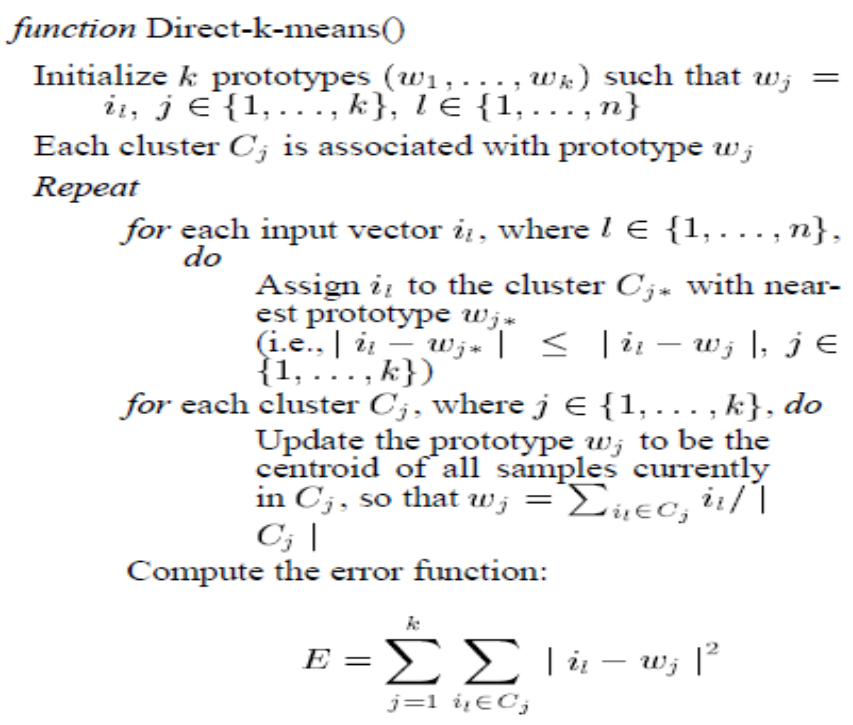

$$
E=\sum_{j=1}^{k} \sum_{i_{t} \in C_{j}}\left|i_{i}-w_{j}\right|^{2}
$$

Until $E$ does not change significantly or cluster membership no longer changes

Gambar 2. Algoritma K-Means (Alsabti., Sanjay Ranka., Vineet Singh, 2010) 


\section{Hasil dan Pembahasan}

\subsection{Lingkup Kerja}

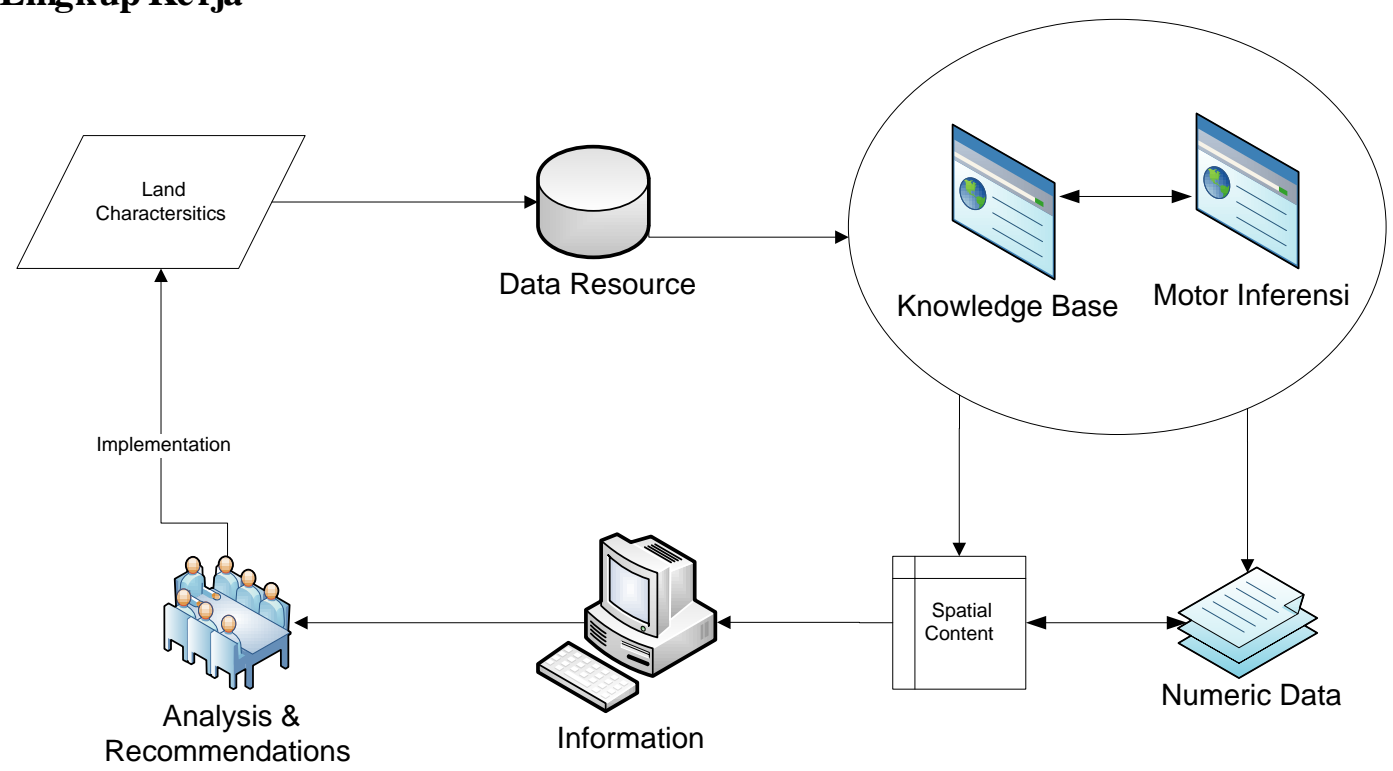

Gambar 3. Alur Data Pengelolaan Lahan

Gambar 3 mendeskripsikan proses pengelolaan data lahan dalam sistem informasi yang dibangun. Lingkungan pengelolaan data dimulai dengan evaluasi karakteristik lahan yang dikumpulkan dalam data resource secara terpusat dan diolah dalam lingkungan role knowledge base dan motor inference. Lingkungan tersebut akan menghasilkan data numerik dan data spasial ditampilkan secara informatif dalam sistem. Informasi tersebut dianalis is dan direkomendasi oleh pakar bidang penge lolaan lahan yang selanjutnya diimplementasikan.

\subsection{Data Karakte ris tik Lahan}

Karakteristik lahan dan pengumpulan data melalui observasi dan pengujian terhadap kemampuan lahan dengan mengacu pada variabel biofisik lahan berupa luas lahan kritis, rata-rata curah hujan pertahun, tekstur tanah, jumlah luas lahan irigasi teknis dan non teknis, iklim dan topografi.

Hasil pengumpulan data di wilayah kabupaten Boyolali didapat data tahun 2010 seperti yang terlihat pada Tabel 1 .

Tabel 1. Data Lahan Per Kecamatan di Wilayah Boyolali Tahun 2010

\begin{tabular}{|c|c|c|c|c|c|c|}
\hline $\begin{array}{l}\text { KECAMATA } \\
\mathrm{N}\end{array}$ & $\begin{array}{l}\text { L_KRITIS } \\
10\end{array}$ & $\begin{array}{l}\text { C_HUJAN } \\
10\end{array}$ & $\begin{array}{l}\text { T_TANA } \\
\mathrm{H}\end{array}$ & $\begin{array}{l}\text { J_IRIGA } \\
\text { SI }\end{array}$ & IKLIM & $\begin{array}{l}\text { TOPOGRA } \\
\text { FI }\end{array}$ \\
\hline JUWANGI & 974.94 & 2,955 & 0.4 & 41 & $\begin{array}{l}5.4314367 \\
6\end{array}$ & 0.6 \\
\hline KEMUSU & 1105.52 & 2,984 & 0.4 & 341 & $\begin{array}{l}5.3786513 \\
49\end{array}$ & 0.3 \\
\hline $\begin{array}{l}\text { WONOSEGO } \\
\text { RO }\end{array}$ & 929.23 & 3,241 & 0.4 & 55 & $\begin{array}{l}4.9521430 \\
5\end{array}$ & 0.5 \\
\hline ANDONG & 697.47 & 2,959 & 0.4 & 0 & 5.4240945 & 0.6 \\
\hline KLEGO & 558.42 & 2,271 & 0.5 & 81 & $\begin{array}{l}7.0673252 \\
42\end{array}$ & 0.6 \\
\hline $\begin{array}{l}\text { KARANGGED } \\
\text { E }\end{array}$ & 124.71 & 3,137 & 0.5 & 432 & $\begin{array}{l}5.1163199 \\
31\end{array}$ & 0.4 \\
\hline SIMO & 60.4 & 3,005 & 0.6 & 156 & $\begin{array}{l}5.3410634 \\
36\end{array}$ & 0.3 \\
\hline NOGOSARI & 0 & 3,360 & 0.5 & 337 & 4.7767546 & 0.2 \\
\hline
\end{tabular}




\begin{tabular}{|c|c|c|c|c|c|c|}
\hline $\begin{array}{l}\text { KECAMATA } \\
\mathrm{N}\end{array}$ & $\begin{array}{l}\text { L_KRITIS } \\
10\end{array}$ & $\begin{array}{l}\text { C_HUJAN } \\
10\end{array}$ & $\begin{array}{l}\text { T_TANA } \\
\mathrm{H}\end{array}$ & $\begin{array}{l}\text { J_IRIGA } \\
\text { SI }\end{array}$ & IKLIM & $\begin{array}{l}\text { TOPOGRA } \\
\text { FI }\end{array}$ \\
\hline SAMBI & 0 & 3,097 & 0.5 & 133 & $\begin{array}{l}5 \\
5.1824009 \\
12\end{array}$ & 0.5 \\
\hline NGEMPLAK & 40 & 2,770 & 0.4 & 149 & $\begin{array}{l}5.7941861 \\
46\end{array}$ & 0.3 \\
\hline $\begin{array}{l}\text { BANYUDON } \\
\mathrm{O}\end{array}$ & 0 & 2,812 & 0.5 & 76 & $\begin{array}{l}5.7076442 \\
48\end{array}$ & 0.3 \\
\hline SAWIT & 0 & 3,382 & 0.5 & 0 & $\begin{array}{l}4.7456817 \\
34\end{array}$ & 0.4 \\
\hline TERAS & 0 & 2,964 & 0.4 & 854 & $\begin{array}{l}5.4149445 \\
43\end{array}$ & 0.3 \\
\hline MOJOSONGO & 3.42 & 2,418 & 0.6 & 0 & $\begin{array}{l}6.6376739 \\
56\end{array}$ & 0.5 \\
\hline BOYOLALI & 0 & 3,214 & 0.6 & 0 & $\begin{array}{l}4.9937447 \\
49\end{array}$ & 0.6 \\
\hline CEPOGO & 1203.74 & 3,645 & 0.5 & 0 & $\begin{array}{l}4.4032635 \\
46\end{array}$ & 0.8 \\
\hline MUSUK & 5552.61 & 3,298 & 0.5 & 0 & $\begin{array}{l}4.8665541 \\
61\end{array}$ & 0.6 \\
\hline SELO & 3106.72 & 4,232 & 0.2 & 150 & $\begin{array}{l}3.7925084 \\
18\end{array}$ & 0.9 \\
\hline AMPEL & 2392.33 & 3,227 & 0.4 & 0 & $\begin{array}{l}4.9736274 \\
01\end{array}$ & 0.7 \\
\hline
\end{tabular}

Data tersebut sudah diolah dan dikelompokan. Angka lahan kritis dihitung dalam satuan $\mathrm{Ha}$, rata-rata curah hujan per tahun dalam mm dan jumlah Ha lahan irigasi. Angka pada kriteria tersebut didapat langsung dari Badan Pusat Statistik dan dinas pertanian. Untuk data tekstur tanah, iklim dan topografi diolah berdasarkan klasifikasi masing-masing.

Klasifikasi tekstur tanah yang dilakukan untuk mendapatkan nilai berupa angka terbagi lima diantaranya kasar (pasir, pasir berlempung) bobot nilai 0 - 0.2, agak kasar (lempung berpasir) bobot nilai $0.21-0.4$, sedang (lempung, lempung berdebu, debu) bobot nilai $0.41-0.6$, agak halus (lempung liat berpasir, lempung liat berdebu, lempung berliat) bobot nilai $0.61-0.8$, halus (liat berpasir, liat berdebu, liat) bobot nilai $0.81-1$.

Klasifikasi iklim yang dilakukan untuk mendapatkan nilai berupa angka menurut Schamidt - Ferguson menggunakan perhitungan banyaknya curah hujan dengan perhitungan rata-rata bulan kering dibagi dengan rata-rata bulan basah dikali dengan $100 \%$.

Klasifikasi topografi dilakukan untuk mendapatkan nilai berupa angka, dibagi dalam lima kelas berdasarkan ketinggian di atas permukaan laut (dpl) diantaranya area dengan ketinggian 0 200 meter dpl diberi bobot 0 - 0.2, ketinggian 201 - 400 meter dpl diberi bobot $0.21-0.4$, ketinggian 401 - 600 meter dpl diberi bobot 0.41 - 0.6, ketinggian 601 - 800 meter dpl diberi bobot $0.61-0.8$ dan ketinggian $>800$ meter dpl diberi bobot $0.81-1$.

\subsection{Pemetaan dan Perhitungan K-Means}

Lingkungan knowledge base dan motor inference selanjutnya mengolah data resource dengan menggunakan metode pengelolaan data untuk menghasilkan peta digital dan perhitungan secara numerik. Di sini digunakan metode K-Means dengan dibantu dengan tool Weka 3.6 dan untuk data spasial menggunakan tool Mapinfo Profesional 7.5.

Mulanya pengelolaan data spasial dilakukan dengan membangun peta tematik kabupaten boyolali. Peta tematik yang dibangun didasarkan pada data pada Tabel 1 yaitu peta tematik lahan kritis, rata-rata curah hujan, tekstur tanah, rigasi, iklim dan topografi yang ditunjukan melalui Gambar 4. 

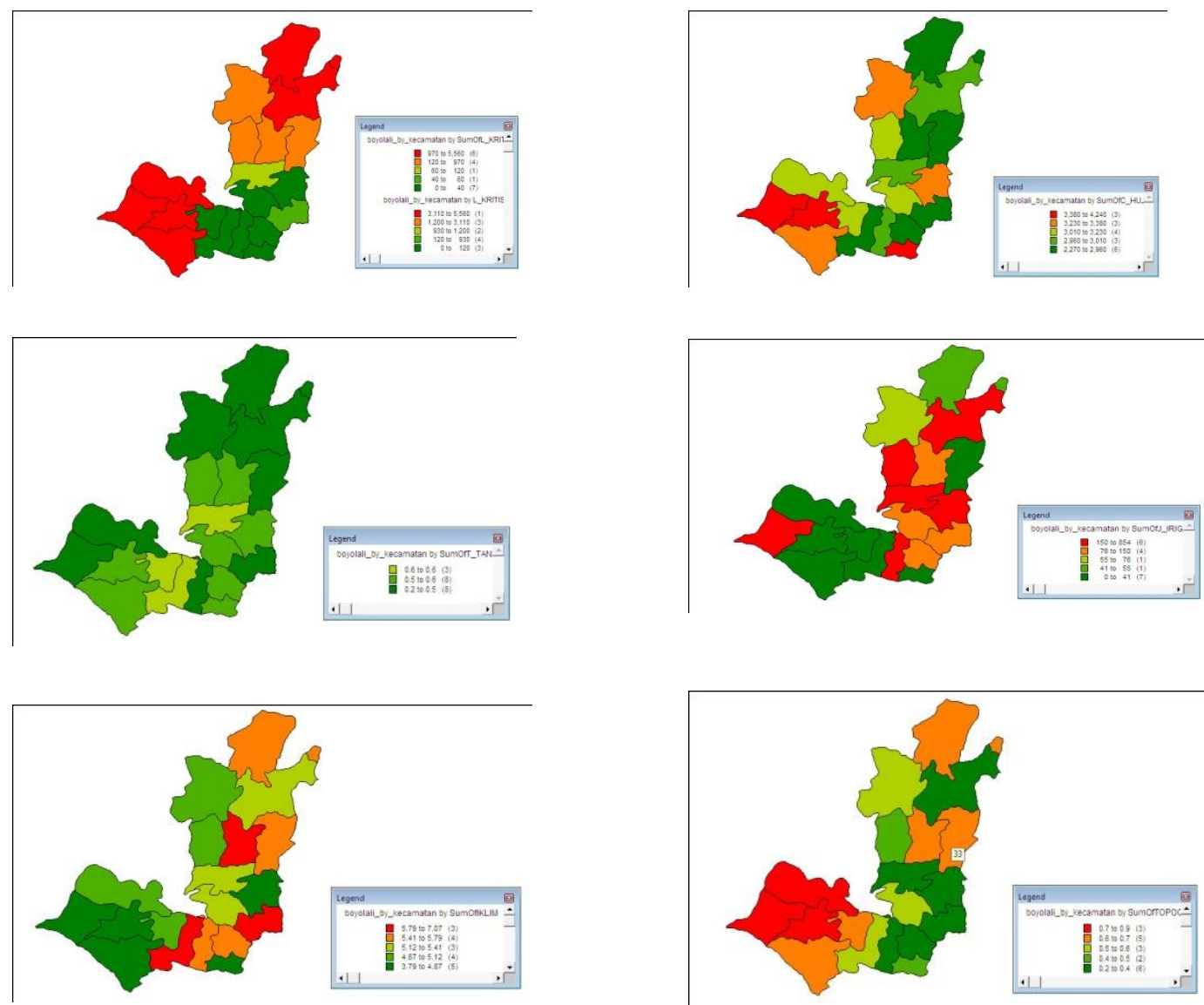

Gambar 4. Peta Tematik Kabupaten Boyolali

Berurutan dari kiri atas ke kanan, kiri bawah ke kanan terdapat peta tematik luas lahan kritis, penyebaran lahan kritis terdapat di barat kabupaten boyolali dan bagian utara boyolali. Jika dilihat penyebab terjadinya lahan kritis ini dipengaruhi oleh bencana erupsi gunung merapi pada bagian barat, bagian utara dipengaruhi oleh iklim dan temperature udara yang tinggi serta curah hujan rendah. Masalah sosial ekonomi kemungkinan berpengaruh tetapi pada laporan ini tidak dibahas lebih rinci.

Pada pengelolaan data dengan algoritma k-means ditentukan:

- Jumlah cluster $=3$;

- $\quad$ Maksimum iterasi $=100$;

- $\quad$ Seed = 10;

- Distance function Ecludean Distance first-last;

Hasil yang didapat dengan perhitungan k-means terdapat rata-rata jumlah cluster error 19.1579. Cluster instance untuk cluster pertama $37 \%$, cluster kedua $42 \%$ dan cluster ketiga $21 \%$. Dengan pusat cluster pada tiap variabel dapat dilihat pada data di bawah ini.

Cluster centroid:

Attribute Full Data $0 \quad 1 \quad 2$
(19)
(7)
(8)
(4)

\begin{tabular}{|c|c|c|c|c|c|}
\hline L_KRITIS10 & 881.5532 & & 615.0829 & 23.5663 & 3063.85 \\
\hline C_HUJAN10 & 2,955 & 2,955 & 3,137 & 3,645 & \\
\hline T_TANAH & 0.4632 & 0.4143 & 0.5375 & 0.4 & \\
\hline J_IRIGASI & 147.6316 & 217.285 & 141.75 & 37.5 & \\
\hline IKLIM & .2632 & 5.6375 & $5.3127 \quad 4.509$ & & \\
\hline
\end{tabular}




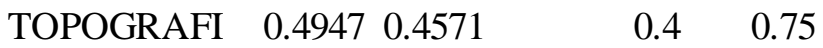

Pada tampilan grafik dipilih dari 12 grafik yang ada dengan variabel topografi sebagai sumbu $\mathrm{X}$ dan lahan kritis sebagai sumbu Y. Alasan pemilihan kedua variabel tersebut karena berdasarkan hasil perhitungan rank dengan Principal Component yang menunjukan kedua variabel tersebut berada pada rank teratas dengan bobot 0.8608 .

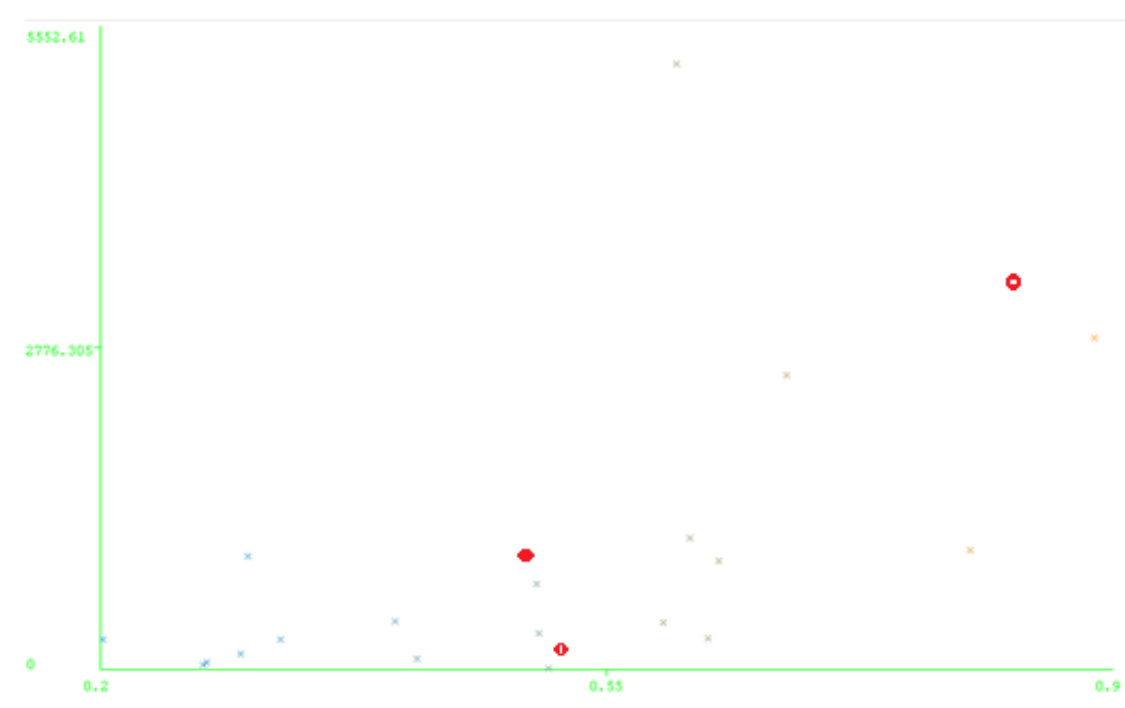

Gambar 5. Grafik Pusat Cluster dan Anggota Cluster

Lahan marginal yang potensial dibuka untuk lahan pangan berdasarkan kriteria yang telah ditentukan adalah anggota cluster yang dekat dengan pusat cluster pertama terdapat pada kecamatan wonosegoro (instance 3) dengan luas lahan marginal 929.23 dengan curah hujan ratarata 3,241 mm, tekstur tanah lempung, lempung berdebu, debu, memiliki saluran irigasi sederhana, iklim dalam setahun stabil dengan topografi ketinggian > 400 meter dpl dan kelerengan < 25 derajat.

Pada cluster kedua, anggota cluster terdekat dengan pusat cluster adalah data kecamatan juwangi dengan luas lahan marginal 974.94 dengan curah hujan rata-rata 2,955 mm, tekstur tanah lempung, lempung berdebu, debu, memiliki saluran irigasi sederhana, iklim dalam setahun stabil dengan topografi ketinggian $>500$ meter dpl dan kelerengan $<25$ derajat.

Pada cluster ketiga, anggota cluster terdekat dengan pusat cluster adalah kecamatan ampel dengan luas lahan marginal 2392.33 dengan curah hujan rata-rata 3,227, tekstur tanah lempung, lempung berdebu, debu, memiliki saluran irigasi sederhana, iklim dalam setahun stabil dengan topografi ketinggian $>500$ meter dpl dan kelerengan $<25$ derajat.

Informasi sebaran data pada setiap cluster menjadi panduan bagi pakar lahan dan pertanian. Referensi informasi dan pemetaan lahan dengan melihat titik cluster terdekat dari pusat cluster dibandingkan dengan peta yang berisi informasi lahan di lapangan. Hal ini membantu para pakar atau pengambil keputusan untuk ada tindak lanjut dari hasil ini.

\section{Simpulan}

Dari hasil pembahasan dan analisis dapat diambil kesimpulan berupa:

- Variabel luas lahan marginal dan topografi menjadi variabel rank dengan yang terpilih dari hasil perhitungan dan analis is.

- Jarak pusat cluster dan anggota cluster terdefinisi dengan je las sehingga sangat cocok dijadikan bahan rekomendasi untuk ahli pertanian dalam mengembangkan potensi lahan dan produksi pangan.

- Model ini dapat digunakan untuk lahan marginal dan jenis lahan lainnya.

Dari penelitian ini saran yang perlu ada lah penelitian lanjutan untuk uji coba model dengan lebih banyak data dan penambahan variabel lainya seperti sosial ekonomi. Saran penelitian lanjutan juga berupa analis is data spasial dalam bentuk time series. 


\section{Daftar Pus taka}

Alsabti Khaled, Sanjaya Ranka, Vinet Singh. An Efficient K-Means Clustering Algorithm. Information Technology Lab (ITL) of Hitachi America Ltd. 2010

Aziz, Anifuddin., Bambang Sunarmito., Medhanita Renanti. Evaluasi Kesesuaian Lahan Untuk Budidaya Tanaman Pangan Menggunakan Jaringan Syaraf Tiruan. Berkala MIPA, 16(1), 2006.

Badan Pusat Statistik Kab. Boyolali. Boyolali Dalam Angka. Boyolali. 2011.

Badan Pusat Statistik Kab. Tapanuli Utara. Survei dan Analisa Ketahanan Pangan Tapanuli Utara. Tarutung. 2005

FAO. A Framework For Land Evaluation Second Printing. FAO and Agriculture Organisation Of The United Nations. Rome. 1981.

Hardjowigeno Sarwono, Widiatmaka. Evaluasi Kesesuaian Lahan dan Perencanaan Tata Guna Lahan. Gajah Mada University Press. 2007

Kaymak Uzay, Magne Setnes. Extended Fuzzy Clustering Algorithms. Erim Report Series Research In Management. Rotterdam. 2000

Sevani Nina, Marimin, Heru Sukoco. Sistem Pakar Penentu Kesesuaian Lahan Berdasarkan Faktor Penghambat Terbesar (Maximum Limitation Factor) Untuk Tanaman Pangan. Jurnal Informatika Vol. 10, No. 1 Mei 2009: 23-31

Sitorus R. P. Santun Dr., Ir., Evaluasi Sumber Daya Lahan. Tarsito. Bandung. 1985 